\title{
Spatial distributions of European clearwing moths (Lepidoptera: Sesiidae)
}

\author{
WERNER ULRICH, MAREK BĄKOWSKI and ZDENĚK LAŠTU゚VKA \\ Nicolaus Copernicus University in Toruń, Department of Animal Ecology, Gagarina 9, 87-100 Toruń; Poland; \\ e-mail: ulrichw@umk.pl \\ Adam Mickiewicz University, Department of Systematic Zoology, Umultowska 89; 61-614 Poznań; Poland; \\ e-mail: bakowski@amu.edu.pl \\ Mendel University in Brno, Department of Zoology, Fisheries, Hydrobiology and Apidology, Zemědělská 1, 61300 Brno, \\ Czech Republic; e-mail: last@mendelu.cz
}

Key words. Lepidoptera, Sesiidae, endemics, widespread species, macro-ecology, spatial auto-regression, latitudinal gradient, longitudinal gradient, coherence, range size, postglacial colonization

\begin{abstract}
Although the sizes of the geographical ranges of plant and animal species are of major interest to macroecologists, the spatial distributions and environmental correlates of only a small group of animals and plants are well studied. Here data on the spatial distributions of 116 European clearwing moths (Sesiidae) was used to determine the patterns in spatial distribution, postglacial colonization and endemism. The spatial distributions of sesiids are significantly more coherent and there are fewer isolated occurrences and unexpected absences than predicted by a random sample null model. After correcting for environmental correlates, islands and mainland countries did not differ significantly in the number of species with small ranges. Polyphagous wood attending species were more widespread than those with other life histories. Species of Siberian origin had wider ranges than those of Mediterranean origin. Nestedness and species co-occurrence analysis did not support a unidirectional postglacial colonization from a Southern European refuge but colonization from both Southern and Eastern Europe.
\end{abstract}

\section{INTRODUCTION}

The sizes of the geographical ranges of plant and animal species are of major interest to macroecologists (reviewed in Gaston, 1996, 2003; Kunin \& Gaston, 1997; Hawkins et al., 2003). Sizes of the ranges of terrestrial organisms tend to be positively correlated with regional abundance (Hartley, 1998; Thompson et al., 1998, Huston, 1999), dispersal ability (Gaston, 1994; Novotny, 1995; Ulrich, 2001; Rundle et al., 2007), evolutionary age of a lineage (Taylor \& Gotelli, 1994, but see BöhningGaese et al., 2006), latitude (Calosi et al., 2009), temporal variability (Vandermeer, 1982), body size (Brown \& Nicoletto, 1991) and niche width (Dennis et al., 2005). In addition, species with small regional ranges are probably influenced by environmental factors that operate at a local or regional scale, whereas widespread species should be less affected by regional factors (e.g. Maurer \& Brown, 1988; Brown, 1995; Jetz \& Rahbek, 2002).

The bio-conservation of species with small ranges, particularly endemic species, is of particular importance (reviewed in Kunin \& Gaston, 1997). Such regionally rare species have a higher probability of extinction (Fagan et al., 2005). In turn, wide spread species are often habitat generalists with either wide niches (Julliard et al., 2004) or were introduced by man and live in anthropogenic habitats (culture followers; Rosenzweig, 2006).

Most of the work on range size distributions of species has focused on a few well studied taxa, like birds (Orme et al., 2006), mammals (Baquero \& Telleria, 2001) and freshwater fish (Tales et al., 2004). Of the invertebrates, particularly butterflies (Ulrich \& Buszko, 2003, 2005) and ground beetles (Kotze et al., 2003) have been studied. The main reason for the little work on invertebrate taxa of major importance is the lack of appropriate spatial data. In addition, most studies focus on single or a few species for which well resolved spatial data are available (e.g. Baquero \& Telleria, 2001). Comparative studies on range size of species belonging to larger taxa are still scarce (Provan \& Bennett, 2008).

In the present study recent compilations (Laštůvka, 2010; Bakowski et al., 2010) of the spatial distribution of European clearwing moths (Sesiidae) were used. Members of this family are not particularly thermophilous, can tolerate a wide range of climatic conditions and occur in habitats at high altitudes and latitudes. Imagines are often heliophilous, but some species fly in the morning or evening. Thus a geographic analysis is unlikely to be particularly biased by climatic constraints at the taxon level and the data should be suitable for a comparative study of the sizes of ranges of species and for testing several hypotheses concerning the postglacial colonization of Europe from glacial refuges. Below sesiid range size refers always to the spatial distribution in Europe (the regional range size). Many European species of sesiid occur outside Europe and have, therefore, a much larger total range size. Six hypotheses proposed to account for the European distribution of clearwing moths will be tested.

1. Clearwing moths are mostly diurnal. Their larvae are endophagous mainly in roots and partly in the stems of herbaceous plants (rhizophagous) and twigs, stem and/or roots of woody plants (xylophagous) (Laštůvka, 1990). 
Species that feed on herbaceous plants are usually less mobile and probably do not leave their habitat. In contrast many xylophagous species are found far away from their host-plants. They are thought to disperse more than their herbaceous plant feeding counterparts. Hence it is predicted that xylophagous clearwing moths have on average larger regional range sizes than rhizophagous species.

2. Most sesiid larvae are oligophagous, but some are monophagous (about 20\%) and polyphagy is rare (Laštůvka, 1990; Špatenka et al., 1996; Laštůvka \& Laštůvka, 2001), e.g. in Synanthedon spuleri. Quinn et al. (1998) report a positive correlation between the number of host plants and regional range size in butterflies, which accords with the postulated niche width - range size relationship. It is predicted that a similar relationship occurs in Sesiidae.

3. According to the classic theory of island biogeography (MacArthur \& Wilson, 1963) islands that are not isolated (most European islands) should have higher numbers of highly dispersive species. In addition, there should be some relict (endemic) species that disperse on these islands (cf. Dapporto \& Dennis, 2009). Islands and mainland areas should also differ in species richness and number of endemics, even after correcting for other factors, such as area, heterogeneity, temperature and latitude, as is reported by Dapporto \& Dennis (2010).

4. Assuming that Europe was colonized post-glacially, mainly from three refuges (or hot spots), Spain, Greece and Turkey (Médail \& Quézel, 1999; Myers et al., 2000; Hobohm, 2003) the prediction is that most of the species with small ranges occur in Southern Europe and there is a latitudinal gradient in range size, with northern European species having larger ranges than their southern European counterparts. In the case of the Eurosiberian species the East Asian refuge seems to be important and the prediction is that the centres of the ranges of these species should be in Northern and Eastern Europe.

5. Nestedness describes a situation where the species composition at poor sites is a true subset of that at rich sites (Patterson \& Atmar, 1986; Ulrich et al., 2009). Nestedness is therefore a special form of species aggregation and the opposite of anti-nestedness in which species tend to avoid each other. Nestedness analysis is used to infer sequences of colonization and extinction, and patterns of species richness along environmental gradients (Ulrich et al., 2009). A postglacial colonization from Southern Europe should result in a nested pattern of occurrence with fewer species in Northern European countries (Cutler, 1991; Patterson \& Atmar, 2000; Ulrich et al., 2009). Colonization from an East Asian refuge also implies a nested pattern along a longitudinal gradient. The existence of two postglacial colonization events from different centres resulting in a lack of nestedness and a significant turnover of species, from south-western to northeastern Europe (Leibold \& Mikkelson, 2002). Nestedness analysis might therefore be used to identify the directions of postglacial colonization events.

6. Species that deviate from the general pattern of colonization from Southern European refuges should also deviate from a nested pattern. Atmar \& Patterson (1993) call these species idiosyncratic and proposed the nestedness temperature metric as a convenient quantification of idiosyncrasy (Ulrich et al., 2009). The temperature metric quantifies the number of unexpected absences and presences and their distance from the hypothetical isocline that divides the completely filled and completely empty parts of the hypothetical completely nested matrix (Atmar \& Patterson, 1993). In the presence of environmental gradients that influence species occurrences the numbers of unexpected absences and presences should be reduced. In turn the absence of gradients and random colonization of species according to the theory of island biogeography should also randomize the numbers of unexpected absences/presences. It is predicted that the order of species occurrences should follow the latitudinal gradient in species richness. In addition, generalist xylophagous species that potentially have little habitat specificity are more often idiosyncratic than the more specialized rhizophagous species.

\section{MATERIAL AND METHODS}

The recent version of Fauna Europaea (Laštůvka, 2010), which includes the latest taxonomic revisions and faunal surveys, was used to update the faunal composition of 60 European countries (mainland) and larger islands (regardless of national affiliation) (Table 1). Russia and some small islands were not included in the analysis because their faunas are poorly known. Double entries in the case of subspecies were corrected. However, seven countries/islands without sesiid species were included, because absences are also of importance for species richness analyses. In total the present paper is based on 116 European species of Sesiidae (Table 1) of which 84 are rhizophagous and 32 xylophagous (Laštůvka \& Laštůvka, 2001, Laštůvka \& Bąkowski, unpubl.). Apart from total species richness per country/island the number of species that occurred only in a given country or island (country/island endemics, below termed endemics), in at most two countries or islands (species with small ranges), in 3 to 4,5 to 8,9 to 16,17 to 32 , and 33 to 63 countries, were determined. The latter are called widespread species.

Based upon environmental variables that are reported to influence sesiid species richness (Bakkowski et al. 2010) the influence of five geographical variables on clearwing moth occurrence, was evaluated. For each European country and larger island (Table 1), the area in $\mathrm{km}^{2}$ and the latitude and longitude of its geographical centroid, were determined. Centroids were estimated from multiple longest diagonals using Google Earth. Weatherbase(http://www.weatherbase.com) was used to compile data on average annual temperatures $\mathrm{T}_{\text {mean }}$, numbers of days with temperatures below $0^{\circ} \mathrm{C}\left(\mathrm{N}_{\mathrm{T}<0}\right.$ as a proxy for winter length), mean temperatures in January $\mathrm{T}_{\text {January }}$ and July $\mathrm{T}_{\text {July }}$ and to estimate yearly temperature differences $\Delta \mathrm{T}=\mathrm{T}_{\text {July }}-\mathrm{T}_{\text {January }}$. Averaged climate data for each country was not used because in many cases high mountain areas biased the data. Further, the sizes of different countries inflated temperature ranges for larger countries.

To correct for spatial autocorrelation the simultaneous autoregression model (Lichstein et al., 2002; Bini et al., 2009; Beale et al., 2010) with generalized least squares estimation, which is implemented in the Spatial Analysis in Macroecology 4.0 (SAM) package of Rangel et al. (2006), was used. This model uses an additive linear estimation model that is corrected for 
TABLE 1. Countries/islands, area, latitude and longitude of the capitals/largest cities, total species richness, number of country/island endemics and number of species in 6 logarithmic occurrences classes, included in the present study. The numbers in brackets show the number of occurrences taking the range outside Europe into account.

\begin{tabular}{|c|c|c|c|c|c|c|c|c|c|c|c|c|}
\hline \multirow[b]{2}{*}{ Country/Island } & \multirow{2}{*}{$\begin{array}{l}\text { Island/ } \\
\text { Mainland }\end{array}$} & \multirow{2}{*}{$\begin{array}{l}\text { Area } \\
{\left[\mathrm{km}^{2}\right]}\end{array}$} & \multirow{2}{*}{$\begin{array}{l}\text { Centroid } \\
\text { latitude }\end{array}$} & \multirow{2}{*}{$\begin{array}{l}\text { Centroid } \\
\text { longitude }\end{array}$} & \multirow{2}{*}{$\begin{array}{l}\text { Number } \\
\text { of species }\end{array}$} & \multirow{2}{*}{$\begin{array}{l}\text { Country/ } \\
\text { Island } \\
\text { endemics }\end{array}$} & \multicolumn{6}{|c|}{ Occurrences } \\
\hline & & & & & & & 2 & $3-4$ & $5-8$ & $9-16$ & $17-32$ & $33-44$ \\
\hline Albania & $\mathrm{m}$ & 28748 & 40.7 & 20.3 & 40 & 0 & 0 & 0 & $3(1)$ & 6 & 21 & 10 \\
\hline Andorra & $\mathrm{m}$ & 468 & 42.5 & 1.61 & 3 & 0 & 0 & 0 & 0 & 0 & 2 & 1 \\
\hline Austria & $\mathrm{m}$ & 83871 & 47.5 & 14.9 & 47 & $1(1)$ & 0 & 0 & $1(1)$ & $8(4)$ & 27 & 10 \\
\hline Azores & $\mathrm{i}$ & 2200 & 38.3 & -27.1 & 0 & 0 & 0 & 0 & 0 & 0 & 0 & 0 \\
\hline Balearic Islands & $\mathrm{i}$ & 5014 & 39.5 & 2.9 & 8 & 1(1) & 0 & 1 & 0 & 0 & 3 & 3 \\
\hline Belarus & $\mathrm{m}$ & 207650 & 53.4 & 28.2 & 15 & 0 & 0 & 0 & 0 & 0 & 5 & 10 \\
\hline Belgium & $\mathrm{m}$ & 30528 & 50.5 & 4.7 & 20 & 0 & 0 & 0 & 0 & 0 & 10 & 10 \\
\hline Bosnia and Herzegovina & $\mathrm{m}$ & 51197 & 44 & 17.8 & 44 & 0 & 0 & 0 & $2(1)$ & $8(3)$ & 24 & 10 \\
\hline Bulgaria & $\mathrm{m}$ & 110971 & 42.7 & 25.2 & 55 & 1 & $3(1)$ & $2(1)$ & $6(2)$ & $10(4)$ & 24 & 9 \\
\hline Canary Is. & $\mathrm{i}$ & 7270 & 28.1 & -15.2 & 2 & $2(2)$ & 0 & 0 & 0 & 0 & 0 & 0 \\
\hline Channel Is. & $\mathrm{i}$ & 300 & 49.2 & -2.1 & 8 & 0 & 0 & 0 & 0 & 0 & 2 & 6 \\
\hline Corsica & $\mathrm{i}$ & 8680 & 42.1 & 9.1 & 16 & 0 & 0 & 1 & $4(2)$ & 1 & 5 & 5 \\
\hline Crete & $\mathrm{i}$ & 8259 & 35.2 & 24.9 & 19 & $3(2)$ & 0 & 0 & 0 & 2 & 9 & 5 \\
\hline Croatia & $\mathrm{m}$ & 56594 & 45.6 & 16.1 & 53 & 0 & 0 & 0 & $4(3)$ & $11(4)$ & 28 & 10 \\
\hline Cyclades Is. & $\mathrm{i}$ & 2500 & 37 & 25.6 & 0 & 0 & 0 & 0 & 0 & 0 & 0 & 0 \\
\hline Cyprus & $\mathrm{i}$ & 9250 & 35 & 33.1 & 11 & 2 & 0 & 0 & 1 & 2 & 4 & 2 \\
\hline Czech Republic & $\mathrm{m}$ & 78866 & 49.7 & 15 & 43 & 0 & 0 & 0 & $1(1)$ & $7(4)$ & 25 & 10 \\
\hline Denmark & $\mathrm{m}$ & 43093 & 56 & 9.8 & 15 & 0 & 0 & 0 & 0 & 0 & 5 & 10 \\
\hline Dodecanese Is. & $\mathrm{i}$ & 2663 & 39.9 & 27.2 & 2 & 1 & 0 & 0 & 0 & 0 & 1 & 0 \\
\hline Estonia & $\mathrm{m}$ & 45227 & 58.7 & 27.1 & 12 & 0 & 0 & 0 & 0 & 0 & 4 & 8 \\
\hline Faroe Is. & $\mathrm{i}$ & 1399 & 62 & -6.79 & 0 & 0 & 0 & 0 & 0 & 0 & 0 & 0 \\
\hline Finland & $\mathrm{m}$ & 338145 & 64 & 26.5 & 14 & 0 & 0 & 0 & 1 & $1(1)$ & 4 & 8 \\
\hline France & $\mathrm{m}$ & 543965 & 46.6 & 2.8 & 53 & 0 & $1(1)$ & $5(3)$ & $4(4)$ & $6(3)$ & 27 & 10 \\
\hline Germany & $\mathrm{m}$ & 357021 & 51.2 & 10 & 35 & 0 & 0 & 0 & 0 & 2 & 23 & 10 \\
\hline Gibraltar & $\mathrm{i}$ & 6.5 & 36.1 & -5.4 & 4 & 0 & 0 & 0 & 0 & 1 & 1 & 2 \\
\hline Great Britain & $\mathrm{i}$ & 244064 & 53.9 & -2.9 & 16 & 0 & 0 & 0 & 0 & 0 & 7 & 9 \\
\hline Greece & $\mathrm{m}$ & 131992 & 39.3 & 22 & 58 & $8(3)$ & 2 & 2 & $7(3)$ & $7(2)$ & 23 & 9 \\
\hline Hungary & $\mathrm{m}$ & 93054 & 47 & 19.3 & 46 & 0 & 0 & 1 & $1(1)$ & $9(6)$ & 25 & 10 \\
\hline Iceland & $\mathrm{i}$ & 103000 & 64.9 & -19.5 & 0 & 0 & 0 & 0 & 0 & 0 & 0 & 0 \\
\hline Ireland & $\mathrm{i}$ & 70273 & 53.3 & -8.08 & 6 & 0 & 0 & 0 & 0 & 0 & 3 & 3 \\
\hline Italy & $\mathrm{m}$ & 301401 & 42.4 & 12.9 & 55 & 0 & 0 & $5(1)$ & $9(4)$ & $6(2)$ & 25 & 10 \\
\hline Latvia & $\mathrm{m}$ & 64626 & 56.7 & 24 & 13 & 0 & 0 & 0 & 0 & 0 & 4 & 9 \\
\hline Liechtenstein & $\mathrm{m}$ & 160 & 47.1 & 9.5 & 15 & 0 & 0 & 0 & 0 & 1 & 6 & 8 \\
\hline Lithuania & $\mathrm{m}$ & 65318 & 55.3 & 24 & 17 & 0 & 0 & 0 & 0 & $1(1)$ & 6 & 10 \\
\hline Luxembourg & $\mathrm{m}$ & 2588 & 49.8 & 5.9 & 26 & 0 & 0 & 0 & 0 & 0 & 16 & 10 \\
\hline Macedonia & $\mathrm{m}$ & 25339 & 41.5 & 21.7 & 49 & 0 & 0 & $2(1)$ & $5(1)$ & $7(2)$ & 25 & 10 \\
\hline Madeira(Funchal) & $\mathrm{i}$ & 789 & 32.7 & -17 & 1 & 0 & 0 & 0 & 0 & 0 & 0 & 1 \\
\hline Malta & $\mathrm{i}$ & 316 & 35.9 & 14.5 & 4 & 0 & 0 & 0 & 2 & 1 & 0 & 1 \\
\hline Moldova & $\mathrm{m}$ & 33709 & 47.2 & 48.4 & 7 & 0 & 0 & 0 & 0 & 1 & 0 & 6 \\
\hline Monaco & $\mathrm{m}$ & 1.95 & 43.7 & 7.3 & 0 & 0 & 0 & 0 & 0 & 0 & 0 & 0 \\
\hline Netherlands & $\mathrm{m}$ & 41536 & 52.2 & 5.6 & 13 & 0 & 0 & 0 & 0 & 0 & 3 & 10 \\
\hline North Aegean Is. & $\mathrm{i}$ & 3886 & 40 & 25 & 4 & 0 & 0 & 0 & 0 & 1 & 1 & 2 \\
\hline Northern Ireland & $\mathrm{i}$ & 14144 & 54.6 & -6.7 & 3 & 0 & 0 & 0 & 0 & 0 & 1 & 2 \\
\hline Norway & $\mathrm{m}$ & 323963 & 65.2 & 14.5 & 13 & 0 & 0 & 0 & 1 & 0 & 3 & 9 \\
\hline Poland & $\mathrm{m}$ & 312766 & 52.1 & 19.6 & 31 & 0 & 0 & 0 & 0 & $3(2)$ & 18 & 10 \\
\hline Portugal & $\mathrm{m}$ & 91854 & 39.8 & -8.1 & 33 & 0 & 0 & $8(4)$ & $5(4)$ & 1 & 10 & 9 \\
\hline Romania & $\mathrm{m}$ & 237453 & 45.8 & 25 & 54 & 0 & 0 & $3(2)$ & $3(1)$ & $10(3)$ & 28 & 10 \\
\hline San Marino & $\mathrm{m}$ & 61 & 43.9 & 12.6 & 1 & 0 & 0 & 0 & 0 & 0 & 1 & 0 \\
\hline Sardinia & $\mathrm{i}$ & 23813 & 40 & 9.1 & 18 & 0 & 0 & 2 & $5(2)$ & 1 & 5 & 5 \\
\hline Serbia and Montenegro & $\mathrm{m}$ & 102199 & 43.9 & 20.8 & 49 & 0 & 0 & 1 & $4(1)$ & $11(4)$ & 23 & 10 \\
\hline Sicily(Palermo) & $\mathrm{i}$ & 25426 & 37.5 & 14.2 & 28 & $2(1)$ & 0 & 3 & $5(2)$ & 1 & 12 & 5 \\
\hline Slovakia & $\mathrm{m}$ & 49049 & 48.7 & 19.3 & 47 & 0 & 0 & 0 & $1(1)$ & $9(4)$ & 27 & 10 \\
\hline Slovenia & $\mathrm{m}$ & 20273 & 46 & 14.6 & 43 & 0 & 0 & 0 & $3(3)$ & $7(3)$ & 23 & 10 \\
\hline Spain & $\mathrm{m}$ & 505988 & 40.3 & -3.6 & 51 & $3(3)$ & $2(2)$ & $8(3)$ & $5(4)$ & $3(2)$ & 20 & 10 \\
\hline Svalbard \& Jan Mayen & $\mathrm{i}$ & 31000 & 78.5 & 16.6 & 0 & 0 & 0 & 0 & 0 & 0 & 0 & 0 \\
\hline Sweden & $\mathrm{m}$ & 449964 & 62.1 & 16.1 & 17 & 0 & 0 & 0 & 1 & 0 & 6 & 10 \\
\hline Switzerland & $\mathrm{m}$ & 41285 & 46.8 & 8.3 & 34 & 0 & 0 & 0 & 1 & $3(1)$ & 20 & 10 \\
\hline Turkey European part & $\mathrm{m}$ & 23764 & 41.2 & 27.2 & 31 & 0 & $1(1)$ & 0 & 3 & 6 & 14 & 7 \\
\hline Ukraine & $\mathrm{m}$ & 603886 & 49.2 & 30.8 & 44 & 0 & $1(1)$ & $2(2)$ & $2(1)$ & $8(2)$ & 21 & 10 \\
\hline Vatican City & $\mathrm{m}$ & 0.44 & 41.9 & 12.5 & 0 & 0 & 0 & 0 & 0 & 0 & 0 & 0 \\
\hline Total & & & & & 116 & 28 & 6 & 13 & 15 & 14 & 30 & 10 \\
\hline
\end{tabular}


spatial autocorrelation of data (in this case the effect of distance between the capitals of countries/islands). Species richness and area are entered as $\ln$-transformed data. To account for possible peaks of species richness at intermediate latitudes the quadratic term for latitude was also used in this regression analysis. Spatial autocorrelation was quantified using Moran's I (Rangel et al., 2006). Akaike information criterion for model choice, as implemented in SAM, was used. Errors refer to standard errors.

To assess coherence or scatter of range sizes, for each species the average Euclidean distance between the capitals of the countries/islands where a given species occurred, were used. The null expectation of distance was obtained from a random sample model (1000 replicates) in which latitude and longitude were reshuffled among the countries/islands. Significance of coherence or scatter (idiosyncrasy) was obtained from the upper and lower $95 \%$ confidence limits of the null distribution. As further measures of range coherence for each species with at least two occurrences the following were calculated:

(a) the number of isolated occurrences where the country/island was not directly connected (had no borderline) with any other country/island of occurrence and

(b) the number of gaps where the country/island without occurrence was completely surrounded by countries/islands with occurrences.

In the case of islands all the nearest mainland countries were counted as having a direct borderline.

Again the number of isolates and gaps were compared with the predictions of a random sample model in which the species occurrences were reshuffled among countries. The null distribution of expected numbers $\mu$ of isolates or gaps and the respective standard deviation $\sigma$ was again obtained from 1000 replicates. The standardized effect sizes $Z=(x-\mu) / \sigma$ were calculated. Z-scores that are approximately normally distributed indicate statistical significance at the $5 \%$ error level below -2.0 or above 2.0 (two-tailed test).

Nestedness analysis (Ulrich et al., 2009) is a type of ecological gradient analysis that can be used to identify countries/islands with high or low numbers of outlying or missing occurrences (idiosyncrasies). Such countries/islands deviate from the overall pattern of occurrence. To assess the degree of nestedness NODF was used (Almeida-Neto et al., 2008). The method of Atmar \& Patterson (1993) and the temperature metric were used to infer levels of species and site idiosyncrasy. For this task the species $\mathrm{x}$ sites matrix was sorted according to species richness (columns) and total number of occurrences (rows). According to hypotheses 5 and 6 a high degree of nestedness and low numbers of idiosyncratic species was expected. Significant correlations of nestedness ranks with latitude and longitude were also expected.

In addition,species co-occurrence analysis was used to infer whether range sizes are randomly distributed or whether they are segregated (scattered). Matrix wide species segregation was inferred using the C-score (Stone \& Roberts, 1990; Ulrich \& Gotelli, 2007). The approach of Leibold \& Mikkelson (2002) was followed and inferred matrix wide species turnover after one-dimensional seriation (reciprocal averaging) of the coefficient of correlation between row and column matrix entries. Significance levels were in all cases obtained from a conservative null model that preserves occurrence and richness totals (the fixed-fixed model implemented in the sequential swap algorithm, Gotelli, 2000) and has been shown to best account for biases introduced by differences in occurrence (Ulrich \& Gotelli, 2007). A total of $116 \times 60 \times 10=69,600$ swaps were used for each random matrix (cf. Ulrich et al., 2009). Nestedness and co-occurrence calculations were done using $N O D F$ software (Almeida-Neto \& Ulrich, 2011).

\section{RESULTS}

\section{Basic patterns}

Among the 116 species of clearwing moths in Europe $28(24 \%)$ were single country/island endemics (Table 1). Only 10 species $(9 \%)$ occurred in more than 32 of the 60 countries/ islands included in this analysis. Most widespread were Sesia apiformis, Synanthedon myopaeformis (both 45 occurrences), Paranthrene tabaniformis (44), Bembecia ichneumoniformis (43), Synanthedon formicaeformis, S. vespiformis and S. tipuliformis (all 38).

Numbers of occurrences differed with respect to feeding type and life history. Xylophagous species had significantly wider ranges than rhizophagous species and species with at least a biannual development were significantly more widespread than species with a shorter life cycle (Table 2). In addition, there are differences between monophagous and oligo- or polyphagous species, with the latter group being significantly more widespread. Mediterranean and Siberian species also differ significantly in the sizes of their ranges, with the latter group having a higher average number of occurrences (Table 2).

Islands and mainland countries did not differ significantly in the number of species that occurred in only one (single country/island endemics) or two European countries/islands (ANCOVA with area as covariate: $\mathrm{P}>$ 0.3 ; not shown). Greece ( 8 species, of which three are endemics that do not occur anywhere else - Synanthedon geranii, Bembecia fokidensis and Pyropteron umbrifera) and Spain (3, probably only Pyropteron kautzi and P. aistleitneri are endemics) contained the highest numbers of such endemics. In the countries north of the Alps, only Ukraine has a single endemic species, the eastern European and Asian Synanthedon uralensis. Hence, there was a strong latitudinal gradient in the number of species with small ranges.

In the case of widespread species, spatial autoregression modelling revealed that area and differences in mean temperature are significant predictors of species richness (Table 3). In turn, neither winter length nor average annual temperature entered the regression at the $5 \%$ error level.

TABLE 2. Mean number of occurrences of clearwings in 53 European countries/islands according to feeding type and phenology (years of larval development). Differences between means were tested using the Kruskal-Wallis test $(\mathrm{H})$.

\begin{tabular}{|c|c|c|c|c|}
\hline & \multicolumn{2}{|c|}{ Mean number of occurrences } & \multirow{2}{*}{$\mathrm{H}$} & \multirow{2}{*}{$\mathrm{P}$} \\
\hline & Rhizophages & Xylophages & & \\
\hline Feeding type & 9 & 20.1 & 14.55 & 0.0001 \\
\hline Phenology & Yes & No & & \\
\hline Annual & 11.2 & 13.7 & 0.85 & 0.36 \\
\hline Biennual & 13.8 & 11.6 & 1.23 & 0.27 \\
\hline \multirow[t]{2}{*}{ Long living } & 27 & 11.2 & 7. 78 & 0.005 \\
\hline & Monophagous & Oligo/polyphagous & & \\
\hline \multirow[t]{2}{*}{ Food plants } & 10.3 & 18.9 & 7.53 & 0.006 \\
\hline & Mediterranean & Siberian & & \\
\hline Distribution & 10.8 & 23.3 & 9.32 & 0.002 \\
\hline
\end{tabular}


TABLE 3. Richness of widespread ( $>16$ occurrences) sesiid species in European countries/islands. Best fit spatial autocorrelation model $(\mathrm{N}=52) . \mathrm{R}^{2}=0.53 ; \mathrm{P}<0.001$. Area and richness were $\ln$ transformed prior to analysis.

\begin{tabular}{lcccc}
\hline Variable & Coefficient & St. Error & $\mathrm{T}$ & $\mathrm{P}$ \\
\hline Constant & -0.89 & 0.47 & -1.87 & 0.07 \\
Area & 0.24 & 0.05 & 4.96 & $<0.001$ \\
$\Delta \mathrm{T}$ & 0.06 & 0.03 & 2.12 & 0.03 \\
\hline
\end{tabular}

\section{Coherence of range sizes}

As predicted, range size coherence (mean distance between countries/islands) increased with the number of occurrences (Table 4). Multiple regression also revealed a significant increase with mean latitude of occurrence and a significant decrease with mean longitude (Table 4). 66 of the 87 species with at least two occurrences had a significantly more coherent range size than predicted by the random sample model (not shown). None of the species was significantly $(\mathrm{P}<0.05)$ scattered.

The analysis of isolated occurrences confirmed the results of the coherence analysis. Only 8 species had single isolated occurrences: Pennisetia bohemica and Chamaesphecia anatolica (Greece), Chamaesphecia proximata and Ch. alysoniformis (Cyprus), Pyropteron chrysidiformis (Romania), Chamaespecia chalciformis (Italy), Ch. maurusia (Sicily) and Bembecia hymenopteriformis (Spain). In no species did the number of isolates significantly $(\mathrm{P}<0.05)$ exceed the random expectation. In 59 species the observed number of isolates was significantly lower than expected by chance (not shown). In line with the overall low number of isolates there were no significant differences between countries with respect to the total number of species with isolated occurrences in Europe. Cyprus (Chamaesphecia proximata, Ch. alysoniformis) and Greece (P. bohemica, Ch. anatolica) had two isolated occurrences.

Gaps occurred, particularly in small countries at the southern edge of Europe and isolated islands. This is the case for the mainland countries San Marino and Vatican (54), Gibraltar (44) and Andorra (40), and the islands of the Canary Islands (33) and Madeira (32). However, with the exception of Moldova (34) there were no gaps at the northern and eastern boundary of Europe. In accordance with these trends a multiple regression pointed to significant negative associations of the number of gaps with species richness and latitude but not with longitude (Table 5).

TABLE 4. Multiple regression of range size coherence (all species with at least two occurrences) as the dependent and mean latitude and longitude of species range size and numbers of occurrences as independent variables. $\mathrm{N}=87 ; \mathrm{R}^{2}=0.69 ; \mathrm{P}<$ 0.001 .

\begin{tabular}{lcccc}
\hline Variable & Coefficient & St. Error & $\mathrm{T}$ & $\mathrm{P}$ \\
\hline Constant & 1.67 & 3.67 & -0.45 & 0.65 \\
Occurrences & 0.21 & 0.02 & 8.55 & $<0.001$ \\
Mean latitude & 0.27 & 0.09 & 3.11 & $<0.01$ \\
Mean longitude & -0.22 & 0.03 & -7.16 & $<0.001$ \\
\hline
\end{tabular}

TABLE 5. Spatial auto-regression of the number of gaps per country/island as the dependent and latitude, longitude and number of species as independent variables. $N=60 ; R^{2}=0.49$; $\mathrm{P}<0.0001$.

\begin{tabular}{lccrc}
\hline Variable & Coefficient & St. Error & \multicolumn{1}{c}{ T } & $\mathrm{P}$ \\
\hline Constant & 44.31 & 11.44 & 3.87 & $<0.001$ \\
Species richness & -0.45 & 0.09 & -5.14 & $<0.001$ \\
Latitude & -0.63 & 0.19 & -3.35 & $<0.001$ \\
Longitude & -0.04 & 0.13 & -0.26 & 0.80 \\
\hline
\end{tabular}

The analysis of co-occurrence pointed to a significantly scattered (segregated) pattern of spatial distribution (observed C-score: 18.8, expected C-score: 16.1, Z = $24.5, \mathrm{P}<0.0001)$. Separate analyses for northern (above $45^{\circ} \mathrm{N}$ ) and southern European countries (below $45^{\circ} \mathrm{N}$ ) showed that northern (observed C-score: 5.6, expected C-score: 4.0038, $\mathrm{Z}=7.1, \mathrm{P}<0.0001)$ and southern (observed C-score: 5.5 , expected C-score: $4.9, \mathrm{Z}=14.4$, $\mathrm{P}$ $<0.0001)$ European species did not differ in their pattern of spatial distribution. However, this scatter was not accompanied by significant species turnover. The coefficient of correlation between row and column ranks of all 1347 occurrences of the 116 species across 60 countries/islands explained only $6.5 \%$ of the variance and was even lower than expected just by chance (not shown).

TABLE 6. Idiosyncratic country/island nestedness analysis. L95\%CL, U95\%CL: lower and upper 95\% confidence limits of the temperature distribution of 100 randomized matrices. Shown are only the significant countries/islands.

\begin{tabular}{lcccc}
\hline \multirow{4}{*}{ Country/Island } & \multicolumn{3}{c}{$\begin{array}{c}\text { Occur- } \\
\text { rences }\end{array}$} & $\begin{array}{c}\text { Nested- } \\
\text { ness tem- } \\
\text { perature }\end{array}$ \\
& \multicolumn{4}{c}{ Idiosyncratic } \\
\cline { 2 - 5 } Sicily & 28 & 27.35 & 1.99 & U95\%CL \\
Canary Is. & 2 & 21.16 & 1.51 & 10.80 \\
Crete & 19 & 22.51 & 0.90 & 13.38 \\
Portugal & 33 & 20.14 & 3.85 & 15.48 \\
Cyprus & 11 & 18.61 & 3.24 & 13.98 \\
Dodecanese Is. & 2 & 14.27 & 1.16 & 10.55 \\
Sardinia & 18 & 16.05 & 1.05 & 13.19 \\
Baleares & 8 & 13.10 & 2.55 & 12.07 \\
Greece & 58 & 29.33 & 26.60 & 28.68 \\
Andorra & 3 & 13.25 & 1.57 & 12.68 \\
\hline & \multicolumn{4}{c}{ Ordered } \\
Germany & 35 & 1.72 & 2.99 & 16.82 \\
Switzerland & 34 & 2.45 & 3.60 & 18.64 \\
Luxembourg & 26 & 0.95 & 1.92 & 14.51 \\
Czech R. & 43 & 3.66 & 4.51 & 20.99 \\
Netherlands & 13 & 2.18 & 2.64 & 12.60 \\
Slovakia & 47 & 0.16 & 0.60 & 12.39 \\
Bosnia and Herzegovina & 44 & 2.39 & 2.75 & 18.20 \\
Belarus & 15 & 1.66 & 1.97 & 12.76 \\
Belgium & 20 & 0.92 & 1.23 & 11.62 \\
Croatia & 53 & 0.82 & 1.02 & 7.68 \\
Latvia & 13 & 2.06 & 2.24 & 11.54 \\
Romania & 55 & 3.51 & 3.60 & 8.68 \\
Great Britain & 16 & 1.69 & 1.77 & 10.37 \\
Serbia and Montenegro & 49 & 0.46 & 0.47 & 12.05 \\
\hline & \multicolumn{3}{c}{} \\
\hline
\end{tabular}


TABLE 7. Best fit spatial autoregression model of nestedness temperature scores per country/island as dependent and environmental variables as independent variables. $\mathrm{N}=53 ; \mathrm{R}^{2}=0.70 ; \mathrm{P}$ $<0.001$.

\begin{tabular}{lcccr}
\hline Variable & Coefficient & St. Error & $\mathrm{T}$ & $\mathrm{P}$ \\
\hline Constant & 28.23 & 8.76 & 3.22 & $<0.01$ \\
Species richness & 0.16 & 0.13 & 1.43 & 0.15 \\
Longitude & 0.40 & 0.22 & 1.84 & 0.07 \\
$\Delta \mathrm{T}$ & -1.52 & 0.61 & -2.74 & $<0.01$ \\
\hline
\end{tabular}

Contrary to hypothesis 5 the European clearwings did not occur in a nested manner but rather appeared to be antinested (segregated) in comparison to the fixed-fixed null model that accounts for passive sampling effects. The NODF metric for the matrix sorted according to richness and numbers of occurrences was of 47.6, while a score of 53.1 was expected by chance $(\mathrm{Z}=-8.98 ; \mathrm{P}<0.0001)$. The species specific idiosyncrasy analysis identified 12 species as being more and 17 species as being less ordered than expected by chance. Species of both groups did not differ with respect to feeding type and biogeographic origin (pair wise $\mathrm{U}$-tests all $\mathrm{P}>0.1$; not shown).

The nestedness analysis grouped many eastern and central European countries and the Balkan countries as being significantly less idiosyncratic (more ordered) than expected by chance (Table 6). In turn, many southern European countries and particularly islands were identified as being idiosyncratic and therefore having more unexpected occurrences than expected by chance. A spatial autoregression analysis (Table 7) of country/island nestedness and temperature scores pointed to slight (but insignificant) positive correlations of the degree of idiosyncrasy with country/island species richness and longitude and a significant negative correlation with average environmental temperature.

\section{DISCUSSION}

In accordance with the first hypothesis xylophagous species generally have larger ranges than rhizophages (Table 2). However, it should be noted that many xylophages are forest species of Siberian origin, which have now a large Eurosiberian range. In turn, rhizophagous species are generally thermophilous and of Mediterranean origin in a broad sense, which might explain their small ranges. In addition, the large range sizes of oligo- or polyphagous species (Table 2) are in accordance with the second hypothesis and corroborate previous findings on positive correlations of butterfly distributions with the numbers of host plants (Quinn et al., 1988).

Contrary to the third hypothesis, ANCOVA did not indicate differences between islands and mainland countries in terms of the absolute number of single country endemics. Both groups contained five endemic species. Correcting for the lower number of islands (15 islands to 38 mainland countries) does not change this result. The probability of getting five endemics in each group having 100 (mainland) and 55 (island) species is $\mathrm{p}\left(\chi^{2}\right)=0.32$. Thus the tests do not point to differences in the number of endemics between islands and mainland.
In line with the fifth and sixth hypotheses about the colonization of Europe from southern European glacial refugia, the southern European countries Greece and Spain, and the Canary Islands, Cyprus, Crete and Sicily appear to be rich in European endemic species. However, some of these species are not endemic if the surrounding Asian or North African countries are taken into account. The fact that Europe is only a peninsula of the large Asian continent has been neglected in recent studies of large scale spatial distributions. This problem clearly deserves more attention and should be considered in zoogeographical analyses. Many European animal and plant species occupy more or less large extra-European ranges and occur only at the margins of Europe. In the Sesiidae particular species are recorded from Turkey (Tinthia hoplisiformis, Osminia fenusaeformis, Synanthedon rubiana, Bembecia lomatiaeformis, B. stiziformis, B. priesneri, Dipchaspecia lanipes, Chamaespecia gorbunovi and Ch. minor), the Asian part of Russia and Kazakhstan (Synanthedon serica, S. martjanovi), or northern Africa (Bembecia flavida). Only $10(8 \%)$ species of clearwing moths are single country/island endemics in Europe if the insufficient knowledge of the spatial distribution (Bembecia sareptana, B. volgensis, Weismanniola agdistiformis, etc.) and unclear taxonomic status of some species (Synanthedon cruciati, Chamaesphecia staudingeri, C. amygdaloidis, etc.) are taken into consideration.

On the other hand, of the ten most widely distributed European species (Sesia apiformis, Synanthedon myopaeformis, Paranthrene tabaniformis, Bembecia ichneumoniformis, Synanthedon formicaeformis, S. vespiformis, $S$. tipuliformis, S. culiciformis, Pennisetia hylaeiformis and Synanthedon spheciformis) five (Sesia apiformis, Synanthedon myopaeformis, Bembecia ichneumoniformis, S. vespiformis and $S$. tipuliformis) are limited in their distribution to Europe or the western Palaearctic, and only five occupy much larger trans-Palaearctic (Pennisetia hylaeiformis, Synanthedon formicaeformis, S. spheciformis) or even Holarctic (Paranthrene tabaniformis, Synanthedon culiciformis) ranges. In turn, several other species with large trans-Palaearctic ranges do not have wide distributions in Europe. Some of these species might be underrecorded due to their hidden or inconspicuous ways of life (Sesia melanocephala, S. scoliaeformis, S. flaviventris). Synanthedon polaris is an alpine or arctic species with restricted habitat requirements and Synanthedon martjanovi, S. uralensis and Bembecia sareptana are only marginally present in Europe.

The ranges of European clearwing moths are sufficiently known (cf. Laštůvka \& Laštůvka, 2001). The distribution of most species is more or less continuous and only a few have isolates at various distances. These single or two country isolates could be due either by specific habitat requirements (Chamaesphecia palustris), idiosyncratic postglacial spread combined with characteristic habitat requirements (Synanthedon polaris), lack of faunistic data (Pennisetia bohemica, Chamaesphecia anatolica) or the fact that the species range is at the margin of Europe (Bembecia hymenopteriformis, Ch. maurusia). 
The isolated occurrences of some species might also be based on questionable data (for instance Pyropteron chrysidiformis in Romania).

The Mediterranean glacial refuge hypothesis assumes (de Lattin, 1949) that species spread from south European refuges to the north leaving a number of glacial relicts and species with small ranges in those regions. The presence $\mathrm{x}$ sites matrix of European Sesiidae sorted them according to latitude of countries/islands and was significantly anti-nested and segregated. Further, central European and Balkan countries appeared to be more ordered than Mediterranean countries/islands (Table 6) and range coherence was positively correlated with latitude and negatively with longitude (Table 4). Thus this analysis detected few coherent ranges, particularly in southeastern European countries/islands, which accords with the refuge and fourth hypothesis.

The species with a wide and coherent distribution in central and northern Europe includes many Eurosiberian species, which are distributed mostly in northern parts of Europe. In contrast to the species of Mediterranean origin, the European species of Siberian origin have large ranges, because the species with small ranges from this refuge remained in eastern or central Asia and did not reach Europe. Thus, there are at least two qualitatively and quantitatively different colonization trajectories. Nestedness analysis is not suitable for determining such multiple divergent gradients. Such matrices are always identified as being either random or segregated, the pattern identified in the present case. Thus the sesiid pattern is best explained by a multiregional model of colonization with different trajectories of colonization and a number of glacial relicts in southern Europe. A similar multiregional colonization has recently been confirmed for ground beetles (Drees et al., 2010) and reptiles (Joger et al., 2007). Further, the existence of a number of micro-, and cryptic refugia (Joger et al., 2007; Provan \& Bennett 2008) should decrease the degree of nestedness in southern European countries and thus increase the degree of scatter in the spatial distribution.

ACKNOWLEDGMENTS. We thank R. Getz and M. Michalak for providing us with climatic data. L. Dapporto provided valuable comments on an earlier version. H. Pearson kindly improved our English. This work was in part supported by a grant from the Ministry of Education, Youth and Sports of the Czech Republic No. MSM6215648905.

\section{REFERENCES}

Almeida-Neto M. \& Ulrich W. 2011: A straightforward computational approach for measuring nestedness using quantitative matrices. Envir. Modell. Software 26: 173-178.

Almeida-Neto M., Guimarães P., Guimarães P.R. JR., Loyola R.D. \& UlRICH W. 2008: A consistent metric for nestedness analysis in ecological systems: reconciling concept and quantification. Oikos 117: 1227-1239.

Atmar W. \& Patterson B.D. 1993: The measure of order and disorder in the distribution of species in fragmented habitat. Oecologia 96: 373-382.
BąKOWSKi M., UlRich W. \& LašTŮVka Z. 2010: Environmental correlates of species richness of European Sesiidae (Lepidoptera). Eur. J. Entomol. 107: 563-570.

BAquero R.A. \& Telleria J.L. 2001: Species richness, rarity and endemicity of European mammals: a biogeographical approach. Biodiv. Conserv. 10: 29-44.

Beale C.M., Lennon J.J., Yearsley J.M., Brewer M.J. \& Elston D.A. 2010: Regression analysis of spatial data. Ecol. Lett. 13: 246-264.

Bini L.M., Diniz J.A.F., Rangel T.F.L.V.B., Akre T.S.B., Albaladejo R.G., Albuquerque F.S., Aparicio A., Araujo M.B., Baselga A., Beck J., Belloce M.I., Bohning-Gaese K., Borges P.A.V., Castro-Parga I., Chey V.K., Chown S.L., De Marco P., Dobkin D.S., Ferrer-Castan D., Field R., Filloy J., Fleishman E., Gomez J.F., Hortal J., Iverson J.B., Kerr J.T., Kissling W.D., Kitching I.J., Leon-Cortes J.L., Lobo J.M., Montoya D., Morales-Castilla I., Moreno J.C., Oberdorff T., Olalla-Tarraga M.A., Pausas J.G., Qian H., Rahbek C., Rodriguez M.A., Rueda M., Ruggiero A., Sackmann P., Sanders N.J., Terribile L.C., VetaAs O.R. \& Hawkins B.A. 2009: Coefficient shifts in geographical ecology: an empirical evaluation of spatial and non-spatial regression. Ecography 32: 193-204.

Böhning-Gaese K., Caprano T., van EwiJk K. \& Veith M. 2006: Range size: Disentangling current traits and phylogenetic and biogeographic factors. Am. Nat. 167: 555-567.

BRown J.H. 1995: Macroecology. University of Chicago Press, Chicago, 269 pp.

BRown J.H. \& Nicoletto P.F. 1991: Spatial scaling of the species composition: Body masses of North-American land mammals. Am. Nat. 138: 1478-1512.

Calosi P., Bilton D.T., Spicer J.I., Votier S.C. \& Atfield A. 2009: What determines a species' geographical range? Thermal biology and latitudinal range size relationships in European diving beetles (Coleoptera: Dytiscidae). J. Anim. Ecol. 79: 194-204.

Cutler A.H. 1991: Nested faunas and extinction in fragmented habitats. Cons. Biol. 5: 496-505.

Dapporto L. \& Dennis R.L.H. 2009: Conservation biogeography of large Mediterranean islands. Butterfly impoverishment, conservation priorities and inferences for an ecological island paradigm. Ecography 32: 169-179.

DAPPORTO L. \& DeNNIS R.L.H. 2010: Skipper butterfly impoverishment on large Mediterranean islands (Lepidoptera Hesperiidae): Deterministic factors and stochastic events. Biodiv. Conserv. 19: 2637-2649.

De Lattin G. 1949: Beiträge zur Zoogeographie des Mittelmeergebietes. Verh. Dt. Zool. Ges. (Suppl.) 13: 143-151.

Dennis R.L.H., Shreeve T.G., Arnold H.R. \& Roy D.B. 2005: Does diet breadth control herbivorous insect distribution size? Life history and resource outlets for specialist butterflies. $J$. Insect Conserv. 9: 187-200.

Drees C., Matern A., von Oheimb G., Reimann T. \& Assmann T. 2010: Multiple glacial refuges of unwinged ground beetles in Europe: molecular data support classical phylogeographic models. In Habel J.C. \& Assmann T. (eds): Relict Species. Springer, Heidelberg, Berlin, pp. 199-215.

Fagan W.F., Aumann C., Kennedy C.M. \& Unmack P.J. 2005: Rarity, fragmentation, and the scale dependence of extinction risk in desert fishes. Ecology 86: 34-41.

Gaston K. 1994: Rarity. Chapman \& Hall, London, 207 pp.

GASTON K.J. 1996: The multiple forms of the interspecific abundance-distribution relationship. Oikos 76: 211-220.

Gaston K.J. 2003: The Structure and Dynamics of Geographic Ranges. Oxford University Press, New York, 280 pp. 
Gotelli N.J. 2000: Null model analysis of species cooccurrence patterns. Ecology 81: 2606-2621.

Hartley S. 1998: A positive relationship between local abundance and regional occupancy is almost inevitable (but not all positive relationships are the same). J. Anim. Ecol. 67: 992-994.

Hawkins B.A., Field R., Cornell H.V., Currie D.J., Guegan J.F., Kaufman D.M., Kerr J.T., Mittelbach G.G., OberdorfF T., O’Brien E.M., Porter E.E. \& Turner J.R.G. 2003: Energy, water, and broad-scale geographic patterns of species richness. Ecology 84: 3105-3117.

Новонм C. 2003: Characterization and ranking of biodiversity hotspots: centres of species richness and endemism. Biodiv. Conserv. 12: 279-287.

Huston M.A. 1999: Local processes and regional patterns: appropriate scales for understanding variation in the diversity of plants and animals. Oikos 86: 393-401.

Jetz W. \& Rahbeк C. 2002: Geographic range size and determinants of avian species richness. Science 297: 1548-1551.

Joger U., Fritz U., Guicking D., Kalyabina-Hauf S., Nagy Z.T. \& WINK T. 2007: Phylogeography of western Palaearctic reptiles - Spatial and temporal speciation patterns. Zool. Anz. 246: 293-313.

Julliard R., Jiguet F. \& Couvet D. 2004: Common birds facing global changes: what makes a species at risk? Glob. Change Biol. 10: 148-154.

Kotze D.J., Niemelä J., O’Hara R.B. \& Turin H. 2003: Testing abundance-range size relationships in European carabid beetles (Coleoptera, Carabidae). Ecography 26: 553-566.

Kunin W.E. \& Gaston K.J. (eds) 1997: The Biology of Rarity. Chapman and Hall, London, 281 pp.

LAŠTƯVKA Z. 1990: Eine Übersicht der Futterpflanzen der europäischen Glasflügler (Lepidoptera, Sesiidae). Acta. Univ. Agric. (Brno), Fac. Agron. 37: 153-162.

LAŠTƯVKa Z. 2010: Sesiidae. In Karsholt O. \& Nieukerken E.J. van (eds): Fauna Europaea: Lepidoptera, Moths. Fauna Europaea, Version 2.2, online at http://www.faunaeur.org/ (as of 3 June, 2010).

LaštưVKa Z. \& LaštůVKa A. 2001: The Sesiidae of Europe. Apollo Books, Stenstrup, 245 pp.

Leibold M.A. \& Mikkelson G.M. 2002: Coherence, species turnover, and boundary clumping: elements of metacommunity structure. Oikos 97: 237-250.

Lichstein J.W., Simons T.R., Shriner S.A. \& Franzreb K.E. 2002: Spatial autocorrelation and autoregressive models ecology. Ecol. Monogr. 72: 445-463.

MacArthur R.H. \& WiLson E.O. 1963: An equilibrium theory of insular zoogeography. Evolution 17: 373-387.

Maurer B.A. \& Brown J.H. 1988: Distribution of energy use and biomass among species of North American terrestrial birds. Ecology 69: 1923-1932.

MÉdail F. \& QuÉzel P. 1999: Biodiversity hotspots in the Mediterranean Basin: Setting global conservation priorities. Conserv. Biol. 13: 1510-1513.

Myers N., Mittermeier R.A., Mittermeier C.G., DA Fonseca G.A.B. \& Kent J. 2000: Biodiversity hotspots for conservation priorities. Nature 403: 853-858.

Novotny V. 1995: Relationships between the life histories of leafhoppers (Auchenorrhyncha - Hemiptera) and their hosts plants (Juncaceae, Cyperaceae, Poaceae). Oikos 73: 33-42.

Orme C.D.L., Davies R.G., Olson V.A., Thomas G.A., Ding T.S., Rasmussen P.C., Ridgely R.S., Stattersfield A.J., Ben- nett P.M., Owens I.P.F., Blackburn T.M. \& Gaston K.J. 2006: Global patterns of geographic range size in birds. PLoS Biol 4: 1276-1283.

Patterson B.D. \& Atmar W. 1986: Nested subsets and the structure of insular mammalian faunas and archipelagos. Biol. J. Linn. Soc. 28: 65-82.

Patterson B.D. \& Atmar W. 2000: Analyzing species composition in fragments. In Rheinwald G. (ed.): Isolated Vertebrate Communities in the Tropics. Bonner Zoologische Monographien 46. Zoologisches Forschungsmuseum Alexander Koenig, Bonn, pp. 9-24.

Provan J. \& Bennett K.D. 2008: Phylogeographic insights into cryptic glacial refugia. Trends Ecol. Evol. 23: 564-571.

Quinn R.M., Gaston K.J. \& Roy D.B. 1988: Coincidence in the distributions of butterflies and their foodplants. Ecography 21: 279-288.

Rangel T.F.L., Diniz-Filho J.A.F. \& Bini L.M. 2006: Towards an integrated computational tool for spatial analysis in macroecology and biogeography. Gl. Ecol. Biogeogr. 15: 321-327.

Rosenzweig M.L. 2006: Beyond set-asides. In Goble D.D., Scott J.M. \& Davis F.W. (eds): The Endangered Species Act at Thirty. Island Press, Washington DC, pp. 259-273.

Rundle S.D., Bilton D.T. \& FogGo A. 2007: By wind, wings or water: body size, dispersal and range size in aquatic invertebrates. In Hildrew A.G., Rafaelli D.G. \& Edmonds-Brown R. (ed.): Body Size: The Structure and Function of Aquatic Ecosystems. Cambridge University Press, Cambridge, pp. 186-209.

Špatenka K., Gorbunov O., Laštưvka Z., TošEvski I. \& Arita Y. 1996: Die Futterpflanzen der paläarktischen Glasflügler (Lepidoptera: Sesiidae). Nachr. Entomol. Ver. Apollo (N. F.) 17: 1-20.

Stone L. \& Roberts A. 1990: The checkerboard score and species distributions. Oecologia 85: 74-79.

Tales E., Keith P. \& Oberdorff T. 2004: Density-range size relationships in French riverine fishes. Oecologia 138: 360-370.

TAYlor C.M. \& Gotelli N.J. 1994: The macroecology of Cyprinella: correlates of phylogeny, body size, and geographical range. Am. Nat. 144: 549-569.

Thompson K., Hodgson J.G. \& Gaston K.J. 1998: Abundancerange size relationships in the herbaceous flora of central England. J. Anim. Ecol. 86: 439-448.

UlRICH W. 2001: Ecological characteristics of rare species: the case of parasitic Hymenoptera. Pol. J. Ecol. 49: 379-389.

UlRich W. \& Buszko J. 2003: Species-area relationships of butterflies in Europe and species richness forecasting. Ecography 26: $365-374$.

UlRiCh W. \& BuszKo J. 2005: Detecting biodiversity hotspots using species-area and endemics-area relationships: The case of butterflies. Biodiv. Conserv. 14: 1977-1988.

UlRiCH W. \& Gotelli N.J. 2007: Disentangling community patterns of nestedness and species co-occurrence. Oikos 116: 2053-2061.

Ulrich W., Almeida-Neto M. \& Gotelli N.G. 2009: A consumer's guide to nestedness analysis. Oikos 118: 3-17.

VANDERMEER J. 1982: To be rare is to be chaotic. Ecology 63: $1167-1168$.

Received November 18, 2010; revised and accepted January 11, 2011 